\title{
Proceeding
}

\section{Study on the master's degree in sciences of sports evaluation and sport for disabled at the University of Salerno, Italy}

\author{
ILARIA SANSEVIERO ${ }^{1}$, FRANCESCO PELUSO CASSESE², ERMINIO FONZO1, GAETANO \\ ALTAVILLA ${ }^{3}$, FRANCESCA D'ELIA ${ }^{1}$ \\ 1 University of Salerno, Italy \\ 2 University of Unicusano, Rome, Italy \\ 3 University of Split, Croatia
}

\begin{abstract}
The training of master students in the sports sector and in adapted physical activity is in evolution for the changing requests of the sports market. An analysis of the state of the art is useful with in-depth analysis of specific cases. The University of Salerno, Italy, has a course of study that has the training objectives on assessment and sports for the disabled. The study aims to analyse, over the last four years, from 2015 to 2019 , the variations of the study plans related to the teachings and their coherence with the objectives through the documentary archive research. The Annual Unique Cards of the master's degree program were consulted and also the data developed by the AlmaLaurea University Consortium on graduating students and on the employment outcomes of graduates after one, three and five years from the conclusion of the studies. Preliminary results show a lack of consistency of study' plans with the training objectives and a limited presence of university in the employment dynamics, these last are limited too. The variation of the study plans was not caused by adaptations of market demands and it seems to be no relationship between university and world of work. This survey aims to understand the strengths and weaknesses of the training system and wants to respond more adequately to the need of skills in the master's degree program and to
\end{abstract}

Corresponding author. University of Salerno, Italy.

E-mail: ilariasanseviero@gmail.com

Supplementary Issue: Winter Conferences of Sports Science. Costa Blanca Sports Science Events, 25-26 January 2019. Alicante, Spain.

JOURNAL OF HUMAN SPORT \& EXERCISE ISSN 1988-5202

(c) Faculty of Education. University of Alicante.

doi:10.14198/jhse.2019.14.Proc2.12 
the need of professionalism to include the graduates in the world of work. Key words: Training; Skills; Graduate; Survey; Employment; Work.

\section{Cite this article as:}

Sanseviero, I., Cassese, F.P., Fonzo, E., Altavilla, G., \& D'Elia, F. (2019). Study on the master's degree in sciences of sports evaluation and sport for disabled at the University of Salerno, Italy. Journal of Human Sport and Exercise, 14(2proc), S239-S244.

doi:https://doi.org/10.14198/ihse.2019.14.Proc2.12 


\section{INTRODUCTION}

The University of Salerno, in Italy, has a master's degree in sciences of Sports Evaluation and Sport for Disabled which sets, therefore, its training objectives on evaluation and sport for the disabled. That is one course degree in Italy and it is the most important graduate path for disabled education in sport (Pisapia, D'Isanto, 2018, Tore et al., 2018, Tiziana et al., 2017). In the other hand it has a significant pedagogical content of physical education and sport (Di Tore et al. 2016, D'Isanto, 2016, Di Tore, D'lsanto, 2016). This course of study arises from the need to analyse the world of sport, sports performance and to modify and to optimize the preparation systems and the methodological and didactic aspects. Furthermore, the course aims to build methodologies and techniques suitable for affirming the right to sport for those who are in situations of disability. The training of master students in the sports sector and in adapted physical activity is always in constant evolution due to the changing requests of the sports market (D'Elia, 2019, D'elia et al., 2018, D'Isanto, 2019, Raiola et al., 2018, Raiola, Di Tore, 2017, Raiola, 2014, 2013). This work is a preliminary research study that wants to reshape and reconfigure the training objectives to improve the training offer. The study aims to analyse during the last 4 years, the variations of the study plans related to the teachings and their coherence with the objectives proposed by the course itself. The data obtained for this work are related to the period 2015-2019.

\section{METHOD}

The procedure is based on archival research through document analysis. The data provided by the Annual Unique Cards of the course of study were used. These cards are a functional management tool for the design, the implementation, the self-evaluation and the re-design of the course of study. It consists of three sections, which are subsequent to a brief presentation of the course of study: sec. A, Training Objectives, in which are described the training objectives that the course of study aims to achieve through the planning and implementation of the course, defining the training application and the expected learning outcomes; sec. B, Students' Experience (attending and not attending), which describes the students' experience in their quantitative aspects (entry data, data during the course and exit data), the proposed study plan, the temporal scan of teaching activities and learning, the learning environment (that are human resources and infrastructures made available); sec. C, Results of Training, in which the results of the students are described in their quantitative aspects (entry data, data during the course and exit data).

In addition, the following data were used: - data processed by the AlmaLaurea university consortium taken from questionnaires filled out by graduating students upon preparation of the necessary documentation to be able to take the final exam / degree exam; - data from the survey conducted by AlmaLaurea on graduates' employment outcomes after one, three and five years from the end of their studies, in order to monitor the graduates' employment in the world of work.

\section{RESULTS}

Below there is a table explaining the documentary archive research for the 2015/2016 academic year and there is a brief summary of the changes that took place during the following years. 


\section{Academic years 2015/2019}

Presentation of the course of study: The course provides for incoming specific moments of assessment of the initial basic knowledge necessary to follow the course of study. At the master's degree Program can access not only students coming from ISEF and from L-22 class, but also graduates of the L-19 class.

The course:

a) allows to graduate to participate in the selections to access the Active Training Internship to acquire the qualification for physical education in the first and second level secondary school;

b) prepares technological-didactic, analysis and planning skills, which can be spent in schools, in socioeducational structures, in professional and amateur sports, with particular reference to the field of disability.

Training aim: Graduates, operating under autonomy and / or dependency regime, can perform activities such as:

- design and implement special sports and sports activities both in school and out-of-school settings;

- analyse and evaluate motor-sports performance in the professional and amateur field;

- ability to evaluate and select the training and performance methods in the sports and motor context.

The main employment opportunities:

- Educators in the field of motor and sporting sciences with an integrative character also for the activities for disabled people; - Experts in motor and sports evaluation in professional sports and in amateur sports; - Experts of Sports-adapted ; - Expert movement analysts at private clinics and rehabilitation centres; Experts of analysis and motor and sports evaluation used to support the personal trainer.

The course prepares for the profession of: Specialists in the education and training of people with disabilities; Instructors of non-competitive sports disciplines; managers of sporting events and sports facilities; - Coaches and sports technicians.

The course includes a training program that presents cultural, methodological and technical-practical characteristics that can be traced back to the maturing of knowledge and skills in the field: educational, pedagogical-didactic, communicative-relational, biological, institutional, sporting and medical.

Students' Experience: The University of Salerno records the opinions of students through the compilation of online questionnaires. In addition, it makes use of the data taken from the questionnaires posed by the AlmaLaurea consortium to graduating students.

Both attending and non-attending students gave the average overall assessment a medium-high opinion. Among the undergraduates: only $54 \%$ regularly attended more than $75 \%$ of the scheduled courses; $46 \%$ are overall satisfied with the degree course; $80 \%$ would enrol again in the same course and at the same university.

Results of Training: The course of studies makes use of the survey carried out by the AlmaLaurea Consortium on the employment outcomes of graduates after one, three and five years from the conclusion of their studies.

Occupational condition:

- 1 year post-graduation: $42 \%$;

-3 years post-graduation: $56 \%$;

-5 years post graduate: -.

Employees who, at work, use the skills acquired with the degree to a high degree:

-1 year post-graduation: $80 \%$;

-3 years post-graduation: $50 \%$;

-5 years post graduate: - .

The preliminary results obtained show imperceptible changes during the following years. The results, in fact, indicate a lack of consistency of the study plans with the training objectives, which have remained unchanged over the years. Furthermore, there is a limited presence of the university in the occupational dynamics, and 
these last are limited too. The employment status, in fact, has always remained under $50 \%$ in subsequent academic years with a decrease of $29,4 \%$ in 2017 .

\section{DISCUSSION}

Regarding the variation of the study plans, no major changes have been found. There has been no adaptation to ever-changing market demands and, above all, no relationship between university and the world of work has emerged.

Therefore a check is necessary to adjust any negative aspects. The adjustment should consider the demands of the labour market made up of sports clubs for the disabled and upper secondary schools to improve the school integration of disabled students (Raiola, 2012, 2011ab, Gaetano, 2012).

\section{CONCLUSION}

Therefore, this survey is an important initiative to understand the strengths and weaknesses of the training system and, so, to respond more and more appropriately to the need of skills in the master's degree course taken in consideration and to respond to the need of professionalism to include graduates in the world of work.

\section{REFERENCES}

D‘Elia, F. (2019). The training of physical education teacher in primary school. Journal of Human Sport and Exercise, 14(1proc), S100-S104. https://doi.org/10.14198//hse.2019.14.Proc1.12

D'Elia, F., Mazzeo, F., Raiola, G. (2018)The core curriculum in the university training of the teacher of physical education in Italy, Journal of Human Sport and Exercise, 13(Proc2): S413-S420. https://doi.org/10.14198/ihse.2018.13.Proc2.25

D'Isanto, T. (2019)Physical and sport education between Italian academic system and European Research Council structure panel. Journal of Human Sport and Exercise, 14, S66-S76. https://doi.org/10.14198/jhse.2019.14.Proc1.08

D'Isanto, T. (2016) Pedagogical value of the body and physical activity in childhood [Pedagoška vrijednost tijela i tjelesne aktivnosti u djetinjstvu]. Sport Science, 9, 13-18.

D'Isanto, T., Di Tore, P.A. (2016) Physical activity and social inclusion at school: A paradigm change. Journal of Physical Education and Sport, 16, pp. 1099-1102.

Di Tore, P.A., Schiavo, R., D'Isanto, T. (2016) Physical education, motor control and motor learning: Theoretical paradigms and teaching practices from kindergarten to high school. Journal of Physical Education and Sport, 16 (4), 1293-1297.

Gaetano, R. (2012)Motor learning and didactics into physical education and sport documents in middle school-first cycle of education in Italy, Journal of Physical Education and Sport, 12 (2), 157-163.

Pisapia, F., D'Isanto, T. (2018)Inclusive methods of adaptive training in sprints: A theoretical preliminary study. Journal of Physical Education and Sport, 18, 2101-2105.

Raiola, G. (2017)Motor learning and teaching method, Journal of Physical Education and Sport, 17, 2239 2243.

Raiola, G., Di Tore, P.A. (2017)Motor learning in sports science: Different theoretical frameworks for different teaching methods [Motoričko učenje u sportskoj znanosti: Različiti teorijski okviri zarazličite metode poučavanja] Sport Science, 10, 50-56. 
Raiola, G. (2014)Motor control and learning skills according to cognitive and ecological dynamic approach in a vision on behaviorism, cognitive, Gestalt and phenomenology theories, Mediterranean Journal of Social Sciences, 5 (15), 504-506. https://doi.org/10.5901/miss.2014.v5n15p504

Raiola, G., D'Elia, F., \& Altavilla, G. (2018). Physical activity and sports sciences between European research council and academic disciplines in Italy. Journal of Human Sport and Exercise, 13(2proc), S283-S295. https://doi.org/10.14198/jhse.2018.13.Proc2.13

Raiola, G. (2013)Body knowledge and motor skills, Knowledge Cultures, 1 (6), 64-72.

Raiola, G. (2011a)A study on Italian primary school rules: Neurophysiological and didactics aspects in physical education and sport, Journal of Physical Education and Sport, 11 (2), 43-48.

Raiola, G. (2011b)Study between neurophysiological aspects and regulation documents on preschool in Italy, Journal of Physical Education and Sport, 11 (1), 42-47.

Tiziana, D., Antonetta, M., Gaetano, A. (2017)Health and physical activity [Zdravlje i tjelesna aktivnost] Sport Science, 10 (1), 100-105.

Tore, A.D., Altavilla, G., D'Isanto, T. (2018)Situation awareness in sports science: Beyond the cognitive paradigm, Sport Science, 11 (1), 25-28. 